Katrin Althans

\title{
Geoff Rodoreda, The Mabo Turn in Australian Fiction
}

\author{
Oxford: Peter Lang, 2018. 268 pp., ISBN 978-1-78707-264-0, EUR 73,45
}

In his book 'The Mabo Turn in Australian Fiction', the first volume published in the newly established Australian Studies: Interdisciplinary Perspectives series by Peter Lang, Geoff Rodoreda examines what he calls a "'seismic shift' in Australian fiction writing" (p. 3). Analysing 19 novels published after the Australian High Court's decision in 'Mabo and Others v Queensland (No. 2)', which overturned the doctrine of 'terra nullius', Rodoreda argues for understanding "postMabo not only as a temporal marker but also as denoting new discourses [...] in contemporary Australian fiction" (p. 24). The Mabo decision, he writes, marks a turning point in Australian literary history (as it did in other fields, such as law, history, film, or politics) which nevertheless does not feature highly on the agenda of literary critics - a gap Rodoreda seeks to fill with his book, "the first to propose a typology of post-Mabo fiction for both Aboriginal and non-Aboriginal authored novels" (p. 4). This distinction structures the book as a whole and also is a key element of the double meaning Rodoreda attaches to the term "postMabo," which refers to both "writing after Mabo, by non-Aboriginal authors" and "fiction beyond Mabo, by Indigenous authors" (pp. 24 f.). Despite the obvious heterogeneity which you expect in a study of 19 novels by 17 different authors and a time span of 21 years (1993-2014), Rodoreda arranges them within four key thematic fields which form the four main chapters of his book. His taxonomy includes what he calls "core post-Mabo novels" (ch. 1), novels which re-write the past (ch. 2) and those which re-write the present (ch. 3), and novels by Indigenous authors which are concerned with questions of sovereignty (ch. 4).

While in his introduction Rodoreda presents a discussion of the post-Mabo Australian mindset and the wider discursive practices, in his first chapter he "examine[s] four high-profile, prize-winning novels" he classifies "as exemplary post-Mabo fiction" (p. 35). These novels are David Malouf's 'Remembering Babylon' (1993), Alex Miller's 'Journey to the Stone Country' (2002), Andrew McGahan's 'The White Earth' (2004), and Kate Grenville's 'The Secret River' (2005). Here, Rodoreda analyses the ways in which the representation and understanding of land and country is narratively questioned by inserting the Aboriginal presence in the text. The Aboriginal presence is thus made visible in the texts and challenges the white settler perspective of land and country as "the possession of territory" (p. 59). In this, the textual strategies are reminiscent of the impact of the Mabo decision itself, which similarly made the Aboriginal presence visible in contemporary Australia.

This Aboriginal presence is also the focus of the second chapter, which discusses five historical novels, Liam Davison's 'The White Woman' (1994), Debra 
Adelaide's 'Serpent Dust' (1998), Peter Mew's 'Bright Planet' (2004), and 'Death of a River Guide' (1994) as well as 'Gould's Book of Fish' (2001) by Richard Flanagan. The emphasis here is on history as narrative (p. 79) and how those novels "acknowledge Australia's historical landscape as alive with Indigenous people, their stories, their place names and their cultures" (p. 72). Again, the choice of novels, as Rodoreda writes, is exemplary of a number of historical novels "now being written in post-Mabo Australia in which Aboriginal occupation of the land and Aboriginal dispossession from that land is being portrayed" (ibid.). Although Rodoreda identifies a variety of generic conventions within the analysed historical novels, he nevertheless finds their common denominator: the intersection of history, law, politics, and literary fiction. Furthermore, the author shows the extent to which, despite all their heterogeneity, the narratives of post-Mabo historical novels revolve around the two central issues of either 'terra nullius' or the Mabo decision.

Novels set in contemporary Australia, Dorothy Hewett's 'Neap Tide' (1999), Tim Winton's 'Dirt Music' (2001), 'The Multiple Effects of Rainshadow' (1996) and 'Drylands' (1999) by Thea Astley, and Michelle de Kretser's 'The Lost Dog' (2007) as well as Simone Lazaroo's 'Lost River: Four Albums' (2014) are at the centre of the third chapter. As far as the text corpus is concerned, this is the most diverse chapter in the book and also takes into account migrant writing. As Rodoreda writes, "my task in this chapter is to examine a number of novels published in the wake of the Mabo decision and set in contemporary Australia which reflect a post-Mabo imaginary in relation to discourses on land" (p. 108). Therefore, the focus in this chapter is not on the representation of "Aboriginal/non-Aboriginal relations" (p. 107) but on the acknowledgement of Indigenous occupation. The Mabo decision, if we follow Rodoreda's argument, has caused an epiphany of sorts and generated a coming of age story of Australia, one which was sudden rather than gradual and which spawned a new assessment of contemporary Australia in literature.

Those first three chapters comprise the first part of Rodoreda's study, which is concerned with non-Aboriginal authors and their post-Mabo fiction, writing after Mabo and as a reaction to Mabo. In the second part, which consists of chapter four, Rodoreda introduces the concept of 'sovereignMentality' and the ways in which this idea is central to his discussion of Indigenous authors as writing beyond Mabo. Therefore, a considerable part of this chapter is devoted to theorizing 'sovereignMentality' and to contextualize Indigenous sovereignty in the wake of Mabo, as "Aboriginal narrative prose in the new century has become a literature of sovereignty" (p. 161) and changed its terms of reference from White Australia to "land as Indigenous sovereign space" (p. 162). Rodoreda then analyses four Aboriginal-authored novels, 'Carpentaria' (2006) and 'The Swan Book' (2013) by Alexis Wright, Kim Scott's 'That Deadman Dance' (2010), and Melissa Lucashenko's 'Mullumbimby' (2013) to illustrate his point of calling them "Sovereignty Novels" (p. 161): novels which feature characters who "are shown to take for granted their sovereign custodianship of particular country irrespective of the legal status of their landholding in the narrative" - and thus exhibit "a way of thinking or a state of mind" which Rodoreda terms 'sovereignMentality' 
(p. 162). Sovereignty therefore is the key aspect under which the four novels are analysed, as is its relationship to the Mabo decision, and Rodoreda shows the extent to which all of the novels juxtapose Western understandings of sovereignty (the nation and legal possession of country) and an Aboriginal mindset of sovereignty ('sovereignMentality').

'The Mabo Turn in Australian Fiction' is a thoroughly researched study which breaks new ground in the literary historiography of Australia and offers an innovative way of reading contemporary Indigenous literature. Although the reader realizes the book's origin as a German dissertation due to the very detailed literature review and because too much valuable information has gone into the footnotes, it is not only a survey of literature after Mabo, but also an introduction to a new way of writing Australian literary history. Especially Rodoreda's theory of 'sovereignMentality' and understanding of Sovereignty Novels as a "new genre of Indigenous narrative prose in Australia" (p. 5) are important contributions to the field of Indigenous literary studies. The immense scope of his book, however, also provides moments of weakness, most obviously so with regard to the clearcut distinction the table of contents suggests: it is not made clear why the novels in chapter one, other than being "high-profile, prize-winning novels" (p. 35), are singled out as "core post-Mabo novels" (ibid.; emphasis added) when, thematically, they very much overlap with the following two chapters. What I will happily admit, though, is that they indeed form some kind of blueprint for what is being discussed in chapters two and three and that they, due to their prominent status in Australian literary history, are better suited to illustrate Rodoreda's point than lesser-known novels.

I would like to point out two sub-chapters in particular, that on Kate Grenville's 'The Secret River' (pp. 58-70) and that on Alexis Wright's 'Carpentaria' (pp. 171192), for its analysis of narrating silences (pp. 65-68) and for its detailed narratological analysis of "the sovereignty of orality in the text" (p. 172), respectively. Those very nuanced and in-depth discussions make up for the limits in close reading in, for example, the chapter on David Malouf's 'Remembering Babylon'.

Rodoreda ends his tour de force through Australian literary history postMabo by making use of the model of cultural dominance. This allows him to slightly shift his own (thematic) taxonomy to a broader set of classifications, that of dominant, residual, and emergent cultures. At the same time, this opens up new directions for further critical engagement with Australian, especially Aboriginal, literary fiction post-Mabo, as Rodoreda refrains from going into detail when he writes "this cultural strain [Indigenous Sovereignty Novels] is almost as residual as it is emergent" (p. 237): if we do not take white Australian literary history and its anxieties as our terms of reference, we have to understand Sovereignty Novels as being written in a long tradition of Indigenous stories whose residues still resonate in contemporary literature. 